Роман Харченко

Сумській національний аграрний університет ORCID ID 0000-0002-7683-5835

Андрій Леоненко

Сумській державний педагогічний університет імені А. С. Макаренка ORCID ID 0000-0001-5132-9461

Владислава Ганчева

Інститут модернізації змісту освіти МОНУ ORCID ID 0000-0003-0820-4430

Ольга Гончаренко

Сумській державний педагогічний університет імені А. С. Макаренка ORCID ID 0000-0001-9972-6781

Олександр Жуков

Сумській державний педагогічний університет імені А. С. Макаренка ORCID ID 0000-0003-2592-7761

DOI 10.24139/2312-5993/2020.02/175-183

\title{
ВПЛИВ КООРДИНАЦІЙНИХ ВПРАВ НА РОЗВИТОК УВАГИ СТУДЕНТІВ НА ЗАНЯТТЯХ 3 ФІЗИЧНОГО ВИХОВАННЯ
}

В основу даної статті покладено припущення, що природною основою координаційних здібностей є властивості нервової системи, індивідуальні варіанти будови кори головного мозку, ступінь зрілості ії окремих областей, рівень розвитку $і$ збереження сенсорних систем, продуктивність психічних процесів, темперамент, характер, здатність регулювати емоційний стан. Дане дослідження показує, що позитивний фон для коригування уваги можуть створювати вправи для розвитку координаційних здібностей, тому що такі вправи сприяють збільшенню стійкості нервової системи. Проведене дослідження дозволило виявити відмінності між показниками уваги студентів до та після застосування на заняттях з фізичного виховання комплексу координаційних вправ.

Ключові слова: параметри уваги, координаційні здібності, студенти.

Постановка проблеми. Науково-технічний прогрес спричиняє зміни в багатьох галузях людських знань. Це призводить до подальшої інтенсифікації й ускладнення процесу навчання в закладі вищої освіти. Обсяг засвоєння інформації, який щороку збільшується, вимагає від студентської молоді психологічних напружень та фізичних зусиль.

Увага - це одна з необхідних психологічних умов продуктивності розумової діяльності студента на занятті, яка проявляється в їх робочому стані, зосередженості на предметі навчального занятя і на процесі виконання навчальних завдань (Рибалко та Самохвалова, 2020; Харченко та ін., 2019).

Увагу не можна розглядати як окреме, саме по собі існуюче, психічне явище. Вона проявляється лише в процесі будь-якої діяльності людини.

Позитивним фоном для коригування уваги - це стійкість нервової системи. Розподіл ії інтенсивності для повноцінного розвитку всіх 
формованих психофізіологічних процесів відбувається під час виконання тонко координованих рухів (Колумбет, 2014; Самохвалова та ін., 2018).

Як результат функціонування головного мозку, координаційні здібності тісно пов'язані з проявом психічних функцій (увага, пам'ять, мислення). Моторна (рухова) асиметрія $\epsilon$ одним із факторів, які визначають надійність рухових дій, оскільки асиметрія рухів виступає деяким регулятором якісного виконання структури рухів, що характеризує успішність даної діяльності (Куртова та ін., 2018; Хоменко та ін., 2019).

Актуальним $€$ питання пошуку методів оптимізації уваги для підвищення ефективності процесу навчання студентської молоді.

Аналіз актуальних досліджень. Аналізуючи наукову літературу 3 даної проблеми, можна зауважити, що Ланге дослідив, як увага сприяє сенсомоторній адаптації тобто механізм уваги це сигнал м'язових зусиль, якими характеризується будь-яке напруження, викликане діяльністю, спрямованою на досягнення мети (Узнадзе, 2004, с. 360-361).

А. С. Москальова досліджувала особливості розвитку уваги студентів педагогічних ВНЗ різних спеціальностей на різних етапах навчання. Автор зазначає, що увага студентів, які навчаються на різних спеціальностях, має своєрідні відмінності (Москальова, 2014).

У законі України «Про фізичну культуру і спорт» визначаються необхідні зміни в підходах суспільства до зміщення здоров'я людини до найвищої гуманістичної цінності та пріоритетного напряму державної політики. Зокрема, у комплексній програмі відмічається, що в Україні склалася критична ситуація з станом здоров'я населення. Різко зросла захворюваність, у тому числі на гіпертонію - у три рази, стенокардію - у 2,4 рази, інфаркт міокарда - 30 відсотків. Несприятливі природні умови стали причиною зростання кількості хворих дітей (ДПРФКС).

Майже 90 відсотків дітей, учнів і студентів мають відхилення у здоров'ї, понад 50 відсотків - незадовільну фізичну підготовку, близько 70 відсотків дорослого населення - низький, нижчий за середній, рівні фізичного здоров'я, у тому числі у віці 16-19 років - 61 відсоток, 20-29 років - 67,2, 30-39 років - 66, 40-49 років - 81,5, 50-59 років - 81, 60 років і старше - 98,1 відсоток. Наприкінці століття кількість інвалідів в Україні перевищувала 2 млн. осіб (ДПРФКС).

В останні роки продовжується тенденція до зниження середньої тривалості життя чоловіків і жінок в Україні, яка на 10-15 років нижча, ніж у США, Японії, Франції та інших економічно розвинених країнах.

На основі спеціально проведеного спостереження експерти «Фонду свободи» зробили прогноз: до 2050 року населення України, в умовах нинішніх темпах зниження, може скоротитися на 17 мільйонів і скласти 32 мільйони. 
Прогноз «Фонду Свободи» підтверджується і незалежними спостереженнями, проведеними експертами ООН з проблем демографії. Виходячи з їх висновків, населення України до 2050 року зменшиться майже на $40 \%$, тобто до 32 мільйонів. Таким чином, обидва незалежні прогнози збігаються.

Демографічна ситуація України представляє серйозну небезпеку, що веде до різкого послаблення політичної, економічної та оборонної безпеки.

За даними головного організаційно-мобілізаційного управління Генштабу ВС України з 60 тисяч юнаків, які підпадають під призив кожного року, тільки 15,5 тисяч вважаються практично здоровими (ДПРФКС).

Крім цього, за даними Міністерства освіти і науки України, майже 90 \% українських дітей, учнів і студентів мають відхилення у стані здоров'я, більше 50 \% - незадовільну фізичну підготовку. Кількість дітей-інвалідів в Україні збільшилася на 28,5 тисяч і на цей момент складає 150,3 тис. дітей, більше 78 \% із них - діти 7- 14 років (ДПРФКС).

У багатьох випадках це пов'язано з неефективним застосуванням самостійного оздоровчого тренування. У новітній час, у зв'язку з упровадженням у навчальний процес закладів вищої освіти Болонської системи потребується вдосконалення цього виду діяльності студентів.

Тому стратегічна мета національної системи виховання студентської молоді потребує формування морального, психічного й соматичного здоров'я, осмисленої потреби у фізичному вдосконаленні, формуванні внутрішньої мотивації для самостійних занять фізичною культурою і спортом, оволодіння знаннями та уміннями здорового способу життя (Канішевський С.М.).

Наукові досліди дозволили сформувати найбільш поширене поняття здоров'я. Здоров'я - це психофізичний стан людини, який характеризується відсутністю патологічних змін і функціональним станом, достатнім для повноцінної біосоціальної адаптації та збереження фізичної та психологічної працеспроможності в умовах природного середовища життєдіяльності.

Використання засобів фізичної культури для оптимізації цього положення значною мірою буде пов'язане із застосуванням індивідуальних тренувально-оздоровчих програм (ІТОП) і міцних мотиваційних психосоціальних установок на зміцнення та збереження здоров'я.

Розвиток сенсомоторної уваги у першокурсників, як однієї зі складових психомоторної активності студентів, проаналізувала С. М. Кондратюк (Кондратюк, 2013).

У ході дослідження визначено особливості прояву та розвитку уваги в студентському віці, а також ії зв'язок із успішністю навчання (Рибалко та ін., 2016; Харченко та ін., 2019; Хоменко та ін., 2019).

Мета дослідження: проаналізувати вплив координаційних вправ на зміни показників уваги (стійкість, концентрація, розподіл) у студентів педагогічного університету. 


\section{Завдання дослідження:}

1. Провести аналіз науково-методичної літератури з досліджуваної проблеми.

2. Визначити початковий рівень показників уваги студентів та рівень розвитку координаційних здібностей.

3. Дослідити вплив комплексу вправ для розвитку координаційних здібностей на показники уваги.

Для вирішення завдань використовувалися такі методи: аналіз науково-методичної літератури, педагогічне спостереження, психологічне тестування, метод математичної статистики.

Виклад основного матеріалу, У дослідженні взяли участь 34 студенти Сумського державного педагогічного університету імені А. С. Макаренка.

На початку експерименту досліджувались основні властивості уваги: швидкість, обсяг, концентрація, стійкість, розподіл та динаміка перемикання, та рівень розвитку координаційних здібностей студентів.

Для дослідження основних властивостей уваги було використано такі методики:

1. Анкета самооцінки, що дозволяє з'ясувати вік, самопочуття, працездатність, стосунки з викладачами та однокурсниками, матеріальне становище студента та його вольові якості й уподобання.

2. Методика Мюнстерберга, що виявляє міру зосередженості вибірковості уваги.

3. Тест «П'єрона-Рузера», який дозволяє визначити рівень концентрації, вибірковості та швидкості перемикання уваги.

4. Тест «Кільця Ландольта», показники якої ідентифікують такі властивості уваги, як стійкість, обсяг, розподіл, концентрацію, коливання.

Рівень розвитку координаційних здібностей визначався за такими нормативами: тест «Хват падаючої лінійки по Душаніну», проба Ромберга, тест Копилова, човниковий біг 4х9 м.

Було проведено статистичну обробку отриманих даних. 3'ясовано середнє значення для окремо взятих ознак. Вірогідність відмінностей перевірено за допомогою t-критерію Ст'юдента.

Таблиця 1

Динаміка зміни показників уваги студентів на початку експерименту

\begin{tabular}{|l|l|l|}
\hline \multicolumn{1}{|c|}{ № } & \multicolumn{1}{|c|}{ Назва тесту } & \multicolumn{1}{|c|}{ Середнє значення } \\
\hline 1. & Тест Кільця Ландольта & $1106 \pm 2,13 \quad \mathrm{P} \leq 0,05$ \\
\hline 2. & Тест Пьерона-Рузера & $82,34 \pm 2,4 \quad \mathrm{P} \leq 0,05$ \\
\hline 3. & Методика Мюнстерберга & $19,52 \pm 0,12 \quad \mathrm{P} \leq 0,05$ \\
\hline
\end{tabular}

Аналіз тестування на початку експерименту показав, що показники концентрації уваги (тест Пьерона-Рузера) знаходяться на середньому рівні; зосередженості та вибірковості уваги (Методика Мюнстерберга) - на рівні 
нижче за середній. У той самих час, привертає увагу розподіл за швидкістю обробки таблиці коректурної проби «Кільця Ландольта» (кількість знаків, переглянутих студентами за 5 хвилин), інакше кажучи, продуктивність виконання тесту знаходиться на рівні нижче за середній (табл. 1).

На початку експерименту ми провели тестування рівня розвитку координаційних здібностей студентів. Середні показники результатів дослідження представлені в таблиці 2.

Таблиця 2

Рівень розвитку координаційних здібностей студентів на початку експерименту

\begin{tabular}{|l|l|l|}
\hline \multicolumn{1}{|c|}{ № } & \multicolumn{1}{|c|}{ Назва тесту } & \multicolumn{1}{|c|}{ Середнє значення } \\
\hline 1. & Тест «Хват падаючої лінійки по Душаніну», см & $19,51 \pm 0,21$ \\
\hline 2. & Проба Ромберга, с & $18,2 \pm 0,14$ \\
\hline 3. & Тест Копилова, с & $9,35 \pm 1,25$ \\
\hline 4. & Човниковий біг 4х9м, с & $9,9 \pm 1,12$ \\
\hline
\end{tabular}

За результатами досліджень, проведених на початку експерименту, можна зазначити, що рівень розвитку координаційних здібностей студентів знаходяться на рівні нижче за середній.

Для проведення експерименту студентів було розподілено на 2 групи по 17 чоловік у кожній.

Студентам першої групи (ЕГ1) наприкінці кожного заняття 3 фізичного виховання пропонувалося виконувати комплекс вправи для розвитку координаційних здібностей.

У другій групі (ЕГ2) студенти наприкінці заняття з фізичного виховання також виконували комплекс вправи для розвитку координаційних здібностей. Вправи студенти виконували груповим методом. Групи формувалися відповідно до типу нервової системи студентів (тип нервової системи визначався за темпінг-тестом). Студентам зі слабким типом нервової системи збільшувався обсяг навантаження за рахунок збільшення тривалості окремої вправи. У студентів із сильним типом нервової системи збільшувалась інтенсивність навантаження за рахунок збільшення вправ та зменшення часу на їх виконання.

Для складання комплексу використовувались такі вправи:

- гімнастичні вправи динамічного характеру, які одночасно охоплюють основні групи м'язів;

- вправи без предметів і з предметами (м'ячами, гімнастичними палицями, скакалками та ін.);

- прості та складні вправи, що виконуються в змінених умовах, при різних положеннях тіла або його частин, у різні сторони (елементи акробатики (перекиди, різні перекати тощо), вправи в рівновазі;

- вправи з елементами спортивних ігор. 
При цьому, щоб запобігти формуванню динамічного стереотипу, вправи змінювалися за рахунок зміни просторових, часових і динамічних параметрів, а також за рахунок зовнішніх умов, змінюючи порядок розташування снарядів, їх вагу, висоту; змінюючи площу опори або збільшуючи їі рухливість у вправах на рівновагу тощо; комбінуючи рухові навички; поєднуючи ходьбу зі стрибками, біг і ловлю предметів; виконуючи вправи по сигналу або за обмежений час.

Таблиця 3

Динаміка зміни показників уваги студентів в кінці експерименту

\begin{tabular}{|c|l|l|l|l|}
\hline № & \multicolumn{1}{|c|}{ Назва тесту } & \multicolumn{1}{|c|}{ ЕГ1 } & \multicolumn{1}{|c|}{ ЕГ 2} & \\
\hline 11. & Тест Кільця Ландольта & $1643 \pm 2,13$ & $1884 \pm 2,04$ & $\mathrm{P} \leq 0,05$ \\
\hline 22. & Тест Пьерона - Рузера & $85,12 \pm 2,4$ & $87,58 \pm 0,12$ & $\mathrm{P} \leq 0,05$ \\
\hline 33. & Методика Мюнстерберга & $23,87 \pm 0,12$ & $24,12 \pm 0,04$ & $\mathrm{P} \leq 0,05$ \\
\hline
\end{tabular}

За даними експериментального дослідження, наприкінці експерименту з'ясовано, що за тестом Пьерона-Роузера показник в ЕГ1 становлять 85,12 фігури за 60 сек., а в ЕГ 2 - 87,58 фігури, що відповідає середньому рівню.

Результати тесту Кільця Ландольта (кількість фігур за 5 хв.) змінилися в ЕГ 1 до 1642, а в ЕГ 2 - 1884, що свідчить про збільшення продуктивності виконання вправи.

Результати тесту Методика Мюнстерберга (кількість слів за 2 хв.) в ЕГ 1 становить 23,87 слів, що відповідає середньому рівня, а в ЕГ 2 24,12 слова - рівень вище за середній, відсотковий показник помилок уцій групі зменшився на 3,84\%.

Таблиця 4

Рівень розвитку координаційних здібностей студентів наприкінці експерименту

\begin{tabular}{|l|l|l|l|}
\hline \multicolumn{1}{|c|}{ № } & \multicolumn{1}{|c|}{ Назва тесту } & \multicolumn{1}{c|}{ ЕГ1 } & \multicolumn{1}{c|}{ ЕГ 2 } \\
\hline 1. & $\begin{array}{l}\text { Тест «Хват падаючої лінійки по } \\
\text { Душаніну», см }\end{array}$ & $17,3 \pm 1,25$ & $16,4 \pm 0,97$ \\
\hline 2. & Проба Ромберга, с & $20,04 \pm 1,54$ & $22,5 \pm 0,86$ \\
\hline 3. & Тест Копилова,с. & $10,56 \pm 0,29$ & $11,15 \pm 0,34$ \\
\hline 4. & Човниковий біг 4х9, с & $9,52 \pm 1,16$ & $9,23 \pm 2,13$ \\
\hline
\end{tabular}

Також ми перевірили зміни показників розвитку координаційних здібностей студентів (таблиця 4).

У результаті проведення тесту «Хват падаючої лінійки по Душаніну» наприкінці дослідження було виявлено, що середні показники ЕГ2

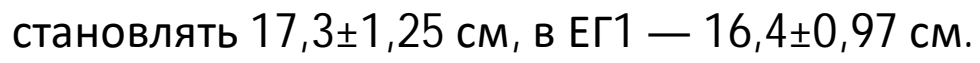

При проведенні тестування розвитку вестибулярної стійкості (проба

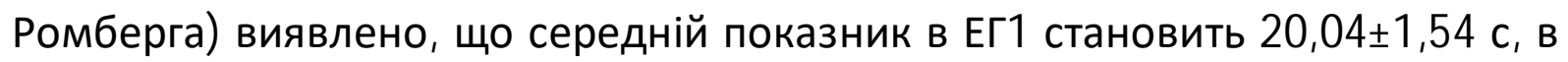

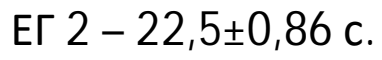


Аналізуючи рівень розвитку міжм'язової координації (тест Копилова),

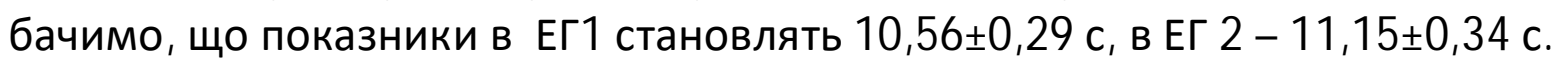

При проведенні човникового бігу 4х9 м виявлено, що показники ЕГ1

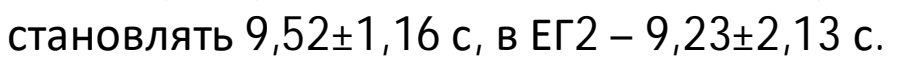

Висновки. Аналіз науково-методичної літератури свідчить, що координаційні здібності тісно пов'язані з проявом психічних функцій, зокрема уваги. Розвиток координаційних здібностей сприяє збільшенню стійкості нервової системи, що $є$ позитивним фоном для коригування уваги, розподілу ії інтенсивності та розвитку всіх формованих психофізіологічних процесів.

У ході дослідження доведено, що врахування типологічних особливостей прояву властивостей нервової системи студентів дає змогу ефективніше формувати рухові навички, які мають складно координаційну структуру, та позитивно впливає на показники уваги студентів

\section{ЛІТЕРАТУРА}

Куртова, Г., Рибалко, П., Красілов, А. (2018). Педагогічні умови формування здоров'язбережувальної компетентності фахівців аграрного сектору у процесі фізичного виховання. Педагогічні науки: теорія, історія, інноваційні технології, 4 (78), 100-111 (Kurtova, P., Rybalko, P., Krasilov, A. (2018). Pedagogical conditions for the formation of health competence of the specialists in the agricultural sector in the process of physical education. Pedagogical sciences: theory, history, innovative technologies, 4 (78), 100-111).

Колумбет, О. М. (2014). Розвиток координаційних здібностей молоді. К.: «Освіта України» (Kolumbet, О. М. (2014). Development of coordination abilities of youth. K.: "Education of Ukraine").

Кондратюк, С. М. (2013). Особливості сенсомоторної уваги студентів першокурсників як одна з умов успішності навчання (дис. ... кандидата психологічних наук). Кам'янець-Подільський (Kondratiuk, S. M. (2013). Peculiarities of sensorimotor attention of first-year students as one of the conditions for academic success (PhD thesis). Kamianets-Podilskyi).

Москальова, А. С. (2014). Методи психодіагностики в навчально-виховному процесі. Київ (Moskaliova, A. S. (2014). Methods of psychodiagnostics in the educational process. Kyiv).

Рибалко, П. Ф., Гвоздецька, С. В., Прокопова, Л. І. (2016). Сучасні підходи до організації фізкультурно-оздоровчої роботи в закладах освіти. Педагогічні науки: теорія, історія, інновачійні технології, 3 (57), 340-347 (Rybalko, P. F., Hvozdetska, S. V., Prokopova, L. I. (2016). Modern approaches to the organization of physical culture and health work in the education institutions. Pedagogical sciences: theory, history, innovative technologies, 3 (57), 340-347).

Рибалко, П. Ф., Самохвалова, І. Ю. (2020). Аналіз розвитку рухових здібностей студенток закладів вищої освіти засобами спортивних ігор у процесі секційних занять (Rybalko, P. F., Samokhvalova, I. Yu. (2020). Analysis of the development of motor abilities of students of higher education institutions by means of sports games in the process of sectional classes). Modern researcher in psychology and pedagogy. Riga: Izdevnieciba "Baltija Publishing", pp. 333-352.

Самохвалова, І. Ю., Мелюшкина, В. В., Рибалко, П. Ф. (2018). Настільний теніс як засіб розвитку координаційних здібностей студентів аграрного університету. Вісник 
Чернігівського національного педагогічного університету. Серія: Педагогічні науки, 151 (1), 133-136 (Samokhvalova, I. Yu., Meliushkina, V. V., Rybalko, P. F. (2018). Table tennis as a means of developing coordination skills of students of the Agricultural University. Bulletin of Chernihiv National Pedagogical University. Series: Pedagogical Sciences, 151 (1), 133-136).

Узнадзе, Д. Н. (2004). Общая психология. М.: Смысл; СПб.: Питер (Uznadze, D. N. (2004). General psychology. M .: Meaning; SPb.: Peter).

Харченко, Р., Хоменко, С., Красілов, А., Рибалко, П. (2019). Методика викладання навчальної дисципліни «Фізичне виховання» у закладі вищої освіти. Педагогічні науки: теорія, історія, інноваційні технології, 5, 183-195 (Kharchenko, R., Khomenko, S., Krasilov, A., Rybalko, P. (2019). Methods of teaching the discipline "Physical Education" in the higher education institution. Pedagogical sciences: theory, history, innovative technologies, 5, 183-195).

Хоменко, О., Рибалко, П., Гудим, М., Гудим С. (2019). Особливості методики розвитку фізичних якостей студентів неспортивних спеціальностей на заняттях фізичною культурою. Педагогічні науки: теорія, історія, інноваційні технології, 6 (90), 174-185 (Khomenko, O., Rybalko, P., Hudym, M., Hudym S. (2019). Peculiarities of the methods of physical qualities development of students of non-sports specialties at physical culture classes. Pedagogical sciences: theory, history, innovative technologies, 6 (90), 174-185).

\section{РЕЗЮМЕ}

Харченко Роман, Леоненко Андрей, Ганчева Владислава, Гончаренко Ольга, Жуков Олександр. Влияние координационных упражнений на развитие внимания студентов на занятиях по физическому воспитанию.

В основу данной статьи положено предположение, что естественной основой координационных способностей являются свойства нервной системы, индивидуальные варианты строения коры головного мозга, степень зрелости ее отдельных областей, уровень развития и сохранения сенсорных систем, производительность психических прочессов, темперамент, характер, способность регулировать эмоциональное состояние. Данное исследование показывает, что положительный фон для корректировки внимания могут создавать упражнения для развития координационных способностей, потому что такие упражнения способствуют увеличению устойчивости нервной системы. Проведенное исследование позволило выявить различия между показателями внимания студентов до и после применения на занятиях по физическому воспитанию комплекса координационных упражнений.

Ключевые слова: параметры внимания, координационные способности, студенты.

\section{SUM MARY}

Kharchenko Roman, Leonenko Andrii, Gancheva Vladyslava, Goncharenko Olha, Zhukov Olekcandr. The impact of coordination exercises on the students' attention development in physical education classes.

Attention in student's activities performs many different functions. It activates the necessary and inhibits unnecessary physiological processes, promotes organized and purposeful selection of information, which comes to the body, provides a selective and longterm concentration of mental processes on a particular activity.

The natural basis of coordination abilities are the properties of the nervous system, individual variants of the structure of the cerebral cortex, the degree of maturity of its individual areas, the level of development and preservation of sensory systems, productivity of the mental processes, temperament, character, ability to regulate emotional state. 
The study involved 34 students of Sumy State Pedagogical University named after A. S. Makarenko. The possibility of the influence of a set of exercises for the development of coordination abilities on changes in attention indicators (stability, concentration, intensity, distribution) in students was determined.

The analysis of literature sources, psychological testing of the level of attention parameters, determination of the level of development of students' coordination abilities, the method of mathematical statistics were used.

The analysis of the scientific and methodological literature has shown that a positive background for the adjustment of attention (distribution, intensity, stability, concentration) can create exercises for the development of coordination skills, because such exercises increase the stability of the nervous system.

The study revealed differences between the indicators of students' attention before and after the application of a set of exercises for the development of coordination skills at physical education classes.

During the experiment, it was found out that students with a weak nervous system mastered difficult coordination skills better when the demonstration of actions had been applied. Individuals with a strong type of nervous system are more successful in mastering complex coordination motor actions when using the method of explanation.

It was experimentally confirmed that the use of a set of exercises to develop coordination skills, taking into account the typological features of the students' nervous system, had improved attention.

Key words: attention parameters, coordination abilities, students.

удк 378.091:005.336.2

\author{
Жанна Чернякова \\ Сумський державний педагогічний \\ університет імені А. С. Макаренка \\ ORCID ID 0000-0003-4547-9388 \\ DOI 10.24139/2312-5993/2020.02/183-195
}

\title{
ФОРМУВАННЯ ФІЗКУЛЬТУРНО-ОЗДОРОВЧОЇ КОМПЕТЕНТНОСТІ МАЙБУТНІХ УЧИТЕЛІВ ФІЗИЧНОЇ КУЛЬТУРИ В ПРОЦЕСІ ВИВЧЕННЯ ПЕДАГОГІЧНИХ ДИСЦИПЛІН
}

У статті представлено теоретичний аналіз різних видів компетентностей у складі фрізкультурно-оздоровчої компетентності вчителя фізичної культури залежно від типів профресійної діяльності, сфери прояву та реалізації певних видів компетентності, функцій професійної діяльності. Схарактеризовано три рівні компетентностей 3 використанням дескрипторів «національної рамки квалірікацій» («знання», «уміння», «комунікація» й «автономність та відповідальність»): інтегральні, загальні та спеціальні. Конкретизовано компоненти структури фрізкультурно-оздоровчої компетентності майбутніх учителів фрізичної культури в прочесі вивчення педагогічних дисциплін у закладі вищої освіти, зокрема, мотиваційно-ціннісний, змістовий, процесуальний, інформаційний та творчий.

Ключові слова: фрізкультурно-оздоровча компетентність, учителі фізичної культури, інтегральні, загальні та спеціальні компетентності, педагогічні дисципліни, заклад вищої освіти.

Постановка проблеми. Модернізація національної системи освіти, що відображає процес євроінтеграції українського суспільства, потреби ринку 